\title{
Total Nonstructural Carbohydrate Trends in Bluebunch Wheatgrass Related to Growth and Phenology
}

\author{
TOM DAER AND E. EARL WILLARD
}

Total nonstructural carbohydrates (TNC) levels in the roots and root crowns of bluebunch wheatgrass (Agropyron spicatum) were analyzed throughout the 1974 growing season. Reserves in root crowns were consistently higher than those in roots, except for the November sample when reserves were similar. The low point in TNC reserves occurred during rapid spring growth when $29 \%$ of the vegetative growth was completed and the average leaf length was $13 \mathrm{~cm}$. Highest levels were attained in the late boot stage when average leaf length was $30 \mathrm{~cm}$ and $67 \%$ of current vegetative growth was completed.

Natural changes in carbohydrate reserves have been studied in many plant species. Reviews by Cook (1966) and White (1973) indicate that the primary source of energy reserve for the growth of perennial grasses is nonstructural carbohydrates stored in roots and root crowns. Carbohydrate reserves are important in perennial plants for winter survival, initiation of new spring and fall growth, and initiation of regrowth following herbage removal when photosynthetic production is not sufficient to supply these needs. Many range and pasture management principles are based on a knowledge of carbohydrate reserve storage and depletion cycles.

Seasonal variation in carbohydrate reserves is not the same for all species. Thus, it is necessary to establish the cycle for each. In the majority of grass species minimum reserve levels occur during early vegetative growth, but lows may also occur during flowering and secondary growth in the fall (Cook 1966).

Our study involved carbohydrate reserves in bluebunch wheatgrass (Agropyron spicatum), one of the most important range grasses on western ranges. Mcllvanie (1942) studied the carbohydrate reserves in bluebunch wheatgrass but did not separate roots from root crowns. He reported that $45 \%$ of the annual growth of bluebunch wheatgrass was produced before reserves ceased to decline. Lows were reached in the roots when the leaf length reached $9-15 \mathrm{~cm}$, and $28 \%$ of the original reserves had been depleted. White (1973) suggested that the major storage areas of carbohydrate reserves in grasses are usually the lower regions of the stems. He questioned whether reserves in roots are used directly in herbage regrowth. Thus, failure to separate roots from root crowns (stem bases) may mask the use of reserves in regrowth.

Objectives of our study were (1) to compare total nonst ructural carbohydrate (TNC) reserves between root crowns and roots and (2) to compare TNC levels to leaf growth and plant phenology.

\section{Site Description}

The experimental area was located at the Johnson-Bell Air Field near Missoula, Montana, at an elevation of $982 \mathrm{~m}$. Grazing had been excluded from the a rea for 20 years and the plant community was judged to be near climax. Associated plant species included prairie junegrass (Koeleria cristata), sandberg bluegrass (Poa sandbergii), cheatgrass (Bromus tectorum), and rubber rabbitbrush (Chrysothamnus nauseosus). The site was located on a

Authors are forestry specialist with the Bureau of Land Management and associate professor, School of Forestry, University of Montana, Missoula, Montana 59812

Manuscript received September 14, 1979. uniform eastern exposure on a $5 \%$ slope.

Mean annual precipitation at the site is $348 \mathrm{~mm}$, the majority of which falls as snow during the winter months. Spring months are normally wet, summers are dry, and some precipitation may accumulate during the fall.

Soils on the arca are weakly calcarcous in the surface horizons and become strongly calcareous in the $\mathrm{Cl}$ horizon $(90-115 \mathrm{~cm}$ below the surface). The upper $40 \mathrm{~cm}$ of soil is a silty clay loam. Soil structure varies from platy at the surface $(0-5 \mathrm{~cm})$ to subangular blocky at lower depths $(5-90 \mathrm{~cm})$.

\section{Methods}

Plant material for determination of total nonstructural carbohydrates was collected throughout the growing season. Two collections were made in March and April, during initial spring growth; four in May during the most active growth; two in June, July, August and September; and one during October and November. Five plants were collected at each sampling date. Each plant collected had an $8-13 \mathrm{~cm}$ crown diameter, thereby reducing the variability of carbohydrate fluctuation due to age and differences in vigor. No young, overmature, or "wolf" plants were collected. All plants were randomly selected.

The leaf length of current season growth and summer-fall regrowth was recorded for each sample plant to relate carbohydrate trends to production of photosynthetic tissue. Leaf lengths of 14 control plants were also measured weekly to determine whether the leaf lengths of sample plants were representative of the general population. Leaf length in our study was defined as the mean length of 10 randomly selected leaf blades on a plant.

The phenological stage of each sample plant was recorded at the time of collection to relate TNC trends to phenology. The following phenological stages were used: $1=$ initial spring growth; $2=$ boot stage; $3=$ seedhead free from boot and flower culm elongating; $4=$ anthesis to milk stage; $5=$ dough stage to seed ripe and dispersal; $6=$ summer dormancy; and $7=$ fall vegetative regrowth.

Sample plants were excavated to a depth of $20 \mathrm{~cm}$. All roots and root crown material was separated and washed thoroughly using a $1 / 16^{\prime \prime}$ mesh screen accompanied by gentle agitation. Dead plant material was separated from all root and crown samples. Samples were then subjected to sub-zero temperatures for 24 hours and transfcrred to a frceze drier for 24 hours. The freeze-dried material was found to contain less than $0.05 \%$ moisture after $24 \mathrm{hrs}$ in the drier. Dried plant material was ground to pass through a 40 -mesh screen, placed in glass bottles, redried, and the bottles sealed.

No more than 2 hours elapsed from the time plants were excavated until the material was frozen; thus, the effect of enzymatic hydrolysis on carbohydrate fractions was kept to a minimum. All samples were collected between $1 \mathrm{pm}$ and $3 \mathrm{pm}$ to minimize variability attributed to diurnal fluctuations. Nonstructural carbohydrate concentrations in plant material is generally lowest at 6 am and increases linearly to a high at $6 \mathrm{pm}$ (Holt and Hilst 1969, Waite and Boyd 1953). We assume, then, that the TNC in our samples were at intermediate levels of diurnal fluctuations. 
Soil temperatures at $10 \mathrm{~cm}$ were taken weekly at five locations between $1 \mathrm{pm}$ and $3 \mathrm{pm}$ throughout the study. Measurements were taken inside grass bunches. Precipitation records for the period were obtained from the U.S. Wcather Bureau station, located at the Johnson-Bell Air Field.

Total nonstructural carbohydrates were determined by colorimetric analysis, involving two perchloric extractions and anthrone as the color reagent. The procedure was a modification of that described by Hassid and Neufeld (1964). Subsamples of $40-50 \mathrm{mg}$ were used so that final TNC concentration fell within the $25 \mu \mathrm{g} / \mathrm{ml}$ to $100 \mu / \mathrm{ml}$ range. The carbohydrate extracted in this procedure include glucose, fructose, sucrose, fructosan, dextrin, inulin, and starch. These components constitute all of the known carbohydrates important in plant processes.

\section{Results and Discussion}

Trends of TNC in the root crown and roots of bluebunch wheatgrass are shown in Figure 1. Concentrations of TNC in root crowns were consistently higher than those in roots throughout the study, except for the November sample when reserve levels were the same. Total TNC in November was greater in the roots, however, due to their greater biomass.

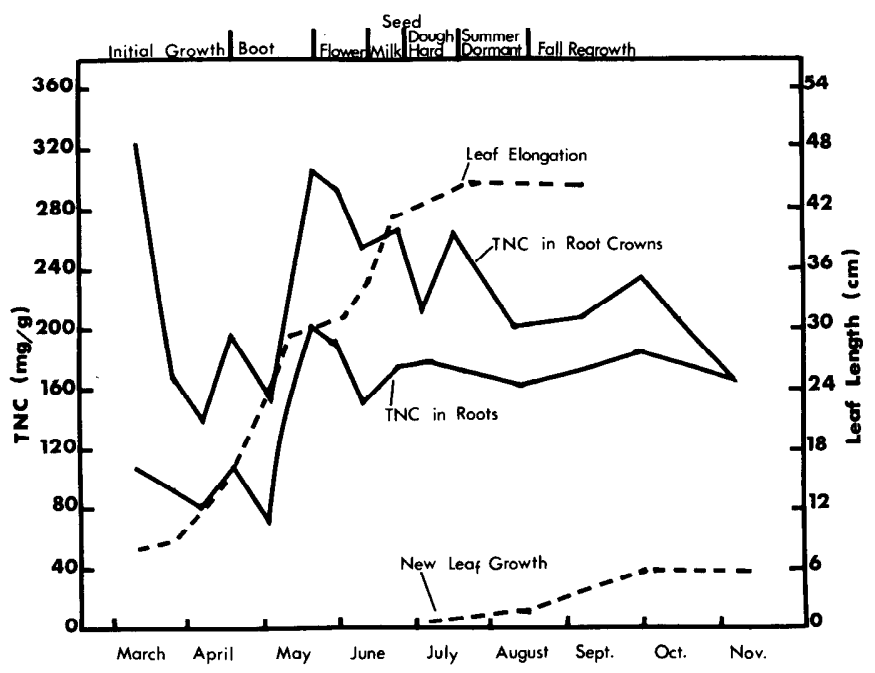

Fig. 1. Total nonstructural carbohydrates in roots and root crowns, and leaf elongation of bluebunch wheatgrass as related to phenology.

Relative fluctuations of reserves in roots and root crowns were similar throughout the first 3 phenological stages. During subsequent stages, root concentrations become more stable than those of the rapidly changing root crown reserves. TNC reserves became depleted during the period of rapid vegetative growth to a low of $140 \mu \mathrm{g} / \mathrm{g}$ in root crowns and $85 \mu \mathrm{g} / \mathrm{g}$ in roots. (Fig. 1). At this point, approximately $29 \%$ of the current vegetative growth had been completed and the average leaf length was $13 \mathrm{~cm}$.

Following the early season low, carbohydrate concentrations increased until the early boot stage (Fig. 1). At this stage of development, when the seed stalk was developing within the boot, TNC reserves were reduced to a low of $158 \mu \mathrm{g} / \mathrm{g}$ in the root crown and $78 \mu \mathrm{g} / \mathrm{g}$ in the roots. Current vegetative growth was $60 \%$ completed and average leaf length was $27 \mathrm{~cm}$.

At some point during the boot stage, when the seed head was more than half way up the boot, carbohydrate reserves began to increase, reaching a peak at $306 \mu \mathrm{g} / \mathrm{g}$ and $202 \mu \mathrm{g} / \mathrm{g}$ in the root crowns and roots, respectively. Average leaf length was $30 \mathrm{~cm}$ and $67 \%$ of the current annual growth had been completed.

Reserves began to decline as the seedhead extruded from the boot and seeds reached the milk stage. Energy requirements of rapid seedhead elongation and early seed development apparently account for the lower reserves. At the beginning of the milk stage through the dough stage in seed development, TNC concentration levels increased slightly. However, deviations in trends arose between root crowns and roots during the dough to seed ripe period. TAC concentrations declined sharply in root crowns during the early stages of the period, then recovered as seeds matured. Concentration levels remained relatively stable in roots during the period. As seeds matured, a depletion of reserves occurred in roots and root crowns to lows of $154 \mu \mathrm{g} / \mathrm{g}$ and $238 \mu \mathrm{g} / \mathrm{g}$, respcctively. High soil temperatures (exceeding $24^{\circ} \mathrm{C}$ at $10 \mathrm{~cm}$ depth) were measured during this period (Fig. 2).

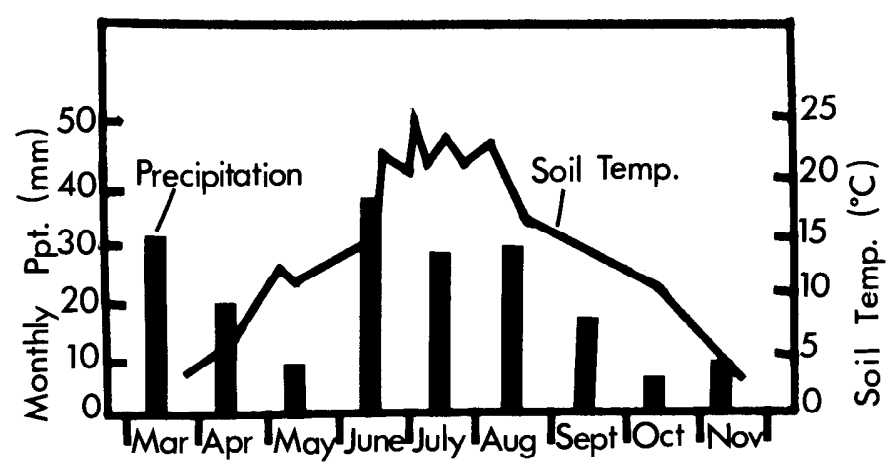

Fig. 2. Soil temperatures and monthly precipitation.

During the seed dispersal stage, carbohydrate reserves began to rise, reaching crown and root concent ration levels of $272 \mu \mathrm{g} / \mathrm{g}$ and $180 \mu \mathrm{g} / \mathrm{g}$, respectively (Fig. 1). Soil moisture was adequate during this period (Fig. 2). This stage marked the end of the current year's vegetative growth with an average leaf length of $45 \mathrm{~cm}$.

Declines in TNC during June and July, especially marked in the root crowns, occurred during the summer dormancy period. Dormancy occurred even though soil moisture was relatively high. This decline in TNC occurred during a period of high air and soil temperatures, and probably more importantly during the initiation of summer-fall regrowth which started during the seed dispersal stage.

Fall regrowth, which involves the development of new leaves, began in July and August with the end of the summer dormancy and the lowering of soil temperatures (Fig. 2). An increase in reserves accompanied fall regrowth until peaks of $238 \mu \mathrm{g} / \mathrm{g}$ and $182 \mu \mathrm{g} / \mathrm{g}$ were reached in the crown and roots, respectively, on October 1 . These peaks coincided with the maximum length for new leaves of $5.5 \mathrm{~cm}$. Increased TNC concentrations during the fall under favorable conditions may be partly attributed to renewed photosynthesis in the current-year culms with some recharge from fall regrowth.

Reserves of TNC declined in both the roots and root crowns during October and November. The faster rate of decline in crown reserves as opposed to a slower rate in root reserves seems to support the contention by White (1973) that reserves for regrowth come mostly from stem bases (or root crowns). Concentrations of TNC in the root crown and roots at the final sampling date (November 10) were both approximately the same $(168 \mu \mathrm{g} / \mathrm{g})$ as opposed to root crown and root reserves of $330 \mu \mathrm{g} / \mathrm{g}$ and $110 \mu \mathrm{g} / \mathrm{g}$, respectively, at the beginning of the growing season.

It is interesting to note that TNC concentrations in bluebunch wheatgrass at the beginning of initial growth in the spring are much higher in root crown than those present when the plants entered winter dormancy. Mcllvanie (1942) made the same observation. The reverse is true for reserves in roots. Transfer of reserves from another storage site to root crown before growth initiation would explain these differences. Since the TNC concentration in roots of bluebunch wheatgrass declines from beginning of winter dormancy until spring green-up, some of the reserves may be translocated into the root crown. Another source of reserves is translocation from culms which die in winter. 
Bluebunch wheatgrass is one of the more palatable forage species in the mountain bunchgrass type and the Palouse prairie. Its ability to compete and remain a significant part of the plant community depends on an adequate supply of carbohydrate reserves for regrowth, and the maintenance of a high state of vigor. Low TNC reserves throughout the early growing season reflect a critical period in its growth and development. Removal of excessive amounts of photosynthetic material during this period may further deplete TNC levels and reduce plant vigor. Grazing should be delayed until the late boot stage when an average leaf length of $20 \mathrm{~cm}$ is attained.

Mueggler (1975) reported that one year of heavy clipping (approximately $50 \%$ of total herbage weight) of bluebunch wheatgrass before complete flower stalk emergence reduced the vigor. Our data show this stage to be high in TNC storage. It is obvious, then, that harvesting less than $50 \%$ of current herbage production is necessary to retain vigourous bluebunch wheatgrass plants.

Reserves are low for a brief period during the late dough stage and again during the initiation of fall regrowth. Although the TNC reserves are not as low during these periods as during initial spring growth, excessive grazing during these later periods might also be expected to reduce plant vigor. Studies have shown that defoliation of grasses late in the growing season may reduce carbohyd rate reserves more than early in the growing season (Sampson and McCarty 1930, Trlica and Cook 1971, Drawe et al. 1972). Reserves apparently do not have sufficient time to recover when plants are defoliated in fall.

\section{Literature Cited}

Cook, C.W. 1966. Carbohydrate reserves in plants. Utah Res. Ser. 31. Logan, Utah. 47 p.

Drawe, D.L., J.B. Grumbles, and J.F. Hooper. 1972. Clipping effects on seeded foothill ranges in Utah. J. Range Manage. 25:426-429.

Hassid, W.Z., and E.F. Neufeld. 1964. Methods in Carbohydrate Chemistry Vol. IV. Academic Press, New York. p. 33-36.

Holt, D.A., and A.R. Hilst. 1969. Daily variation in carbohydrate content of selected forage crops. Agron. J. 61:239-242.

Mcllvanie, S.K. 1942. Carbohydrate and nitrogen trends in bluebunch wheatgrass, Agropyron spicatum, with special reference to grazing influences. Plant Physiol. 17:540-557.

Mueggler, W.F. 1975. Rate and pattern vigor recovery in Idaho fescue and bluebunch wheatgrass. J. Range Manage. 28:198-204.

Sampson, A.W., and E.C. McCarty. 1930. The carbohydrate metabolism of Stipa pulchra. Hilgardia 5:61-100.

Trlica, M.J., Jr. and C.W. Cook. 1971. Defoliation effects on carbohydrate reserves of desert species. J. Range Manage. 24:418-424.

Waite, R., and J. Boyd. 1953. The water-soluble carbohydrates of grasses. I.-Changes occurring during the normal life-cycle. J. Sci. Food Agr. 4:197-204.

White, L.M. 1973. Carbohydrate reserves of grasses: a review. J. Range 26:13-18.

\section{Membership in the Society for Range Management. .}

is open to those engaged in or interested in the study. management, or use of range ecosystems and the intelligent use of all range resources

includes research scientists, ranchers, governmental agency administrators and technical personnel. teachers, students, and people from the business community

provides members with two publications-one oriented to research (Journal of Range Management) and the other oriented to practical resource management (Rangelands) offers opportunities for face-to-face exchange of ideas at local, national, and international meetings of the Society.

Dues vary according to type of membership and geographical section. For application forms and additional information, contact the:

Executive Secretary

Society for Range Management

2760 West Fifth Avenue

Denver, Colorado 80204

(303) 571-0174 